Canadian

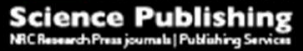

Botany

Botanique

\title{
Sharing of chloroplast haplotypes among red oak species suggests interspecific gene flow between neighboring populations
}

\begin{tabular}{|r|l|}
\hline Journal: & Botany \\
\hline Manuscript ID & cjb-2014-0261.R2 \\
\hline Manuscript Type: & Note \\
\hline Date Submitted by the Author: & 02-Jun-2015 \\
\hline Complete List of Authors: & $\begin{array}{l}\text { Zhang, Ruhua; Linyi University, } \\
\text { Hipp, Andrew; Morton Arboretum, } \\
\text { Gailing, Oliver; Michigan Technological University, }\end{array}$ \\
\hline Keyword: & $\begin{array}{l}\text { chloroplast microsatellites, ecological speciation, Quercus rubra, Q. } \\
\text { ellipsoidalis, Q. velutina }\end{array}$ \\
\hline &
\end{tabular}

\section{SCHOLARONE ${ }^{\text {tm }}$}

Manuscripts 
1 Sharing of chloroplast haplotypes among red oak species suggests interspecific gene flow between neighboring populations

3

4 Ruhua Zhang ${ }^{\mathrm{a}, \mathrm{b}}$, Andrew L. Hipp ${ }^{\mathrm{c}}$, Oliver Gailing ${ }^{\mathrm{a},}$

5

$6 \quad{ }^{a}$ Michigan Technological University, 1400 Townsend Drive, Houghton, Michigan 49931-1295 U.S.A.

$7 \quad{ }^{\mathrm{b}}$ Linyi University, middle part of Shuangling Road, Linyi City, Shandong Province, 276000 China

${ }^{\mathrm{c}}$ The Morton Arboretum, 4100 Illinois Route 53, Lisle, Illinois 60532 U. S. A.

9

10

*: corresponding author: ogailing@mtu.edu

11

12 
13 Abstract: The North American red oak species Quercus rubra, Q. ellipsoidalis, Q. velutina and

14 Q. coccinea are morphologically similar and showed very low interspecific differentiation at 15 most nuclear genetic markers in our earlier analyses $(<10 \%)$. However, a few genetic markers 16 showed interspecific differentiation values (up to $84 \%$ ) above neutral expectations, a pattern of 17 genomic divergence consistent with models of ecological speciation in the face of gene flow and 18 strong divergent selection. Accordingly, these interfertile species are predicted to maintain differential adaptations to drought while neutral regions of the genome appear to be homogenized by interspecific gene flow. According to this model of maintenance of species

21 integrity by divergent selection with gene flow, we expect a sharing of chloroplast haplotypes

22 between interspecific population pairs. We analyzed maternally inherited chloroplast DNA

23 markers for the first time in interspecific populations of the red oaks (section Lobatae) to provide

24 additional evidence for contemporary gene flow between Q. rubra and Q. ellipsoidalis and

25 between $Q$. velutina and Q. ellipsoidalis. Very low interspecific differentiation $\left(\mathrm{G}_{\mathrm{ST}}=0.023\right)$, but

26 pronounced genetic differentiation among populations from different regions $\left(\mathrm{G}_{\mathrm{ST}}=0.277\right)$

27 across species, and sharing of regional chloroplast haplotypes between species in sympatric and 28 neighboring populations provided strong evidence for contemporary interspecific gene flow. The 29 pattern of divergence at chloroplast DNA markers in red oaks suggests interspecific gene flow 30 that resulted in a sharing of chloroplast types while the ecological and morphological distinctness 31 of species was maintained.

32 Keywords: Quercus rubra, Q. ellipsoidalis, Q. velutina, chloroplast microsatellites, ecological 33 speciation. 


\section{Introduction}

Natural hybridization plays an important role in adaptive evolution (Strasburg et al. 2012; Abbott et al. 2013) and the transfer of adaptive genetic variants among species (Arnold 2004; Arnold and Martin 2011). The frequency of hybridization between interfertile species is dependent on pre- and post-zygotic isolation mechanisms, both of which can be affected by the environment (Seehausen et al. 2014). Observational and experimental evidence suggests that selection is a major post-zygotic mechanism in the maintenance of species integrity in hybridizing oaks (Dodd and Afzal-Rafii 2004; Curtu et al. 2007, 2009; de Heredia et al. 2009; Gailing and Curtu 2014; Gailing 2014). Thus, related oak species frequently hybridize in sympatry (Rushton 1993), yet they remain phenotypically and genetically distinct and maintain specific local adaptations for example to drought (Abrams 1990, 1992; Levy et al. 1992; Brendel et al. 2008). At the genome level, interfertile co-occurring European white oak species with different micro-environmental preferences showed a pattern of heterogeneous genomic divergence (Scotti-Saintagne et al. 2004; Goicoechea et al. 2012, 2015) that is predicted as result of strong divergent selection in the face of gene flow (Via and West 2008; Via 2009, 2012).

Genetic marker analyses at genomic and gene-based microsatellite markers indicated interspecific gene flow among $Q$. rubra, Q. ellipsoidalis and Q. velutina, yet species integrity and different adaptations to drought were maintained (Lind and Gailing 2013; Sullivan et al. 2013; Lind-Riehl et al. 2014; Owusu et al. accepted). As in the European white oaks, these species revealed genomic divergence patterns as predicted by models of divergent selection with gene flow, with most markers showing low interspecific differentiation punctuated by gene loci with differentiation values ( $\mathrm{F}_{\mathrm{ST}}$ values) largely above neutral expectations (outlier loci) (Sullivan et al. 2013; Lind-Riehl et al. 2014). For example, CONSTANS-like 1 was identified as outlier 
58 across multiple population pairs of Q. rubra and Q. ellipsoidalis, and was nearly fixed on

59 alternative alleles in both species $\left(\mathrm{F}_{\mathrm{ST}}=0.55-0.84\right)$, while the overall neutral interspecific

60 differentiation was below 10\% $\left(\mathrm{F}_{\mathrm{ST}}<0.10\right)$ (Lind-Riehl et al. 2014; Collins et al. 2015).

61 CONSTANS-like 1 is a candidate gene for flowering time (Yano et al. 2000; Alberto et al. 2013)

62 and is involved in growth and development (Herrmann et al. 2010; Hsu et al. 2012).

63 Additionally, genetic assignment analysis at nuclear DNA markers (genomic and EST-SSRs) in

64 the adult tree, seedling and seed generation provided evidence for gene flow between $Q$. rubra

65 and Q. ellipsoidalis as shown by the presence of putative hybrids and introgressive forms that

66 clustered with their parental species (Lind and Gailing 2013; Collins et al. 2015; Owusu et al.

67 accepted). Likewise genetic assignment analyses at genomic and gene-based SSRs revealed

68 evidence for considerable asymmetric gene flow between $Q$. ellipsoidalis and Q. velutina

69 (Sullivan 2013; Sullivan et al. submitted).

70 While we have evidence for interspecific gene flow based on genetic differentiation patterns at

71 genomic and gene-based SSRs (Lind and Gailing 2013; Sullivan 2013; Lind-Riehl et al. 2014;

72 Collins et al. 2015; Owusu et al. accepted) and genome-wide AFLPs (Hipp and Weber 2008),

73 evidence for shared chloroplast haplotypes expected under interspecific hybridization is missing

74 in the red oaks. Chloroplast DNA analyses in more than 2600 white oak populations across

75 Europe revealed a strong phylogeographic pattern, but a nearly complete lack of interspecific

76 differentiation between the two dominant European white oak species Q. robur and Q. petraea

77 with different soil moisture preferences (Petit et al. 2003b). This lack of differentiation was

78 explained by interspecific gene flow resulting in the invasion of the late-successional species $Q$.

79 petraea into the range of the pioneer species Q. robur (Petit et al. 2003b). 
80 In the present study we adapted universal chloroplast microsatellites (cpSSRs) (Weising and

81 Gardner 1999) and cpSSRs originally developed for Q. robur (Deguilloux et al. 2003) to assess

82 the distribution of cpDNA haplotypes in the red oaks Q. rubra, Q. ellipsoidalis, Q. velutina and

83 Q. coccinea. Uniparental maternal inheritance and the absence of recombination usually result in

84 very low chloroplast haplotype diversity within populations. However, high differentiation

85 across geographic regions within species can be the result of relatively recent population history,

86 such as postglacial recolonization (Palmé et al. 2003; Petit et al. 2003a; Heuertz et al. 2004;

87 Finkeldey and Gailing 2013). On the other hand, sharing of chloroplast types among closely

88 related species in sympatric or neighboring stands indicated interspecific gene flow, for example

89 for oaks, birches and eucalypts (e.g. Petit et al. 2003b; Palmé et al. 2004; Nevill et al. 2014).

90 In this study we selected sites in which the population pairs of Q. rubra-Q. ellipsoidalis and of

91 Q. ellipsoidalis - Q. velutina are sympatric, to test our expectation of shared chloroplast

92 haplotypes. Sharing of regional chloroplast haplotypes between neighboring interspecific

93 population pairs and differentiation among regions independent of the species would strongly

94 implicate recurrent interspecific gene flow. On the other hand, strong differentiation between

95 species would indicate absence of or very limited contemporary interspecific gene flow.

96 According to the model of maintenance of species integrity by divergent selection with

97 interspecific gene flow we expect a sharing of chloroplast haplotypes among interspecific species 98 pairs. 


\section{Materials and methods}

\section{Plant materials}

Samples were collected from 37 populations including 20 Q. rubra populations, $11 Q$. ellipsoidalis populations, five $Q$. velutina populations and one $Q$. coccinea population (Table 1 , Fig. 1, suppl. Fig. 1). Quercus rubra / Q. ellipsoidalis population pairs (sympatric or neighboring stands) were collected from four geographic regions, and Q. velutina / Q. ellipsoidalis population pairs (sympatric stands) were sampled from five geographic regions (Table 1, suppl. Fig. 1). The species show largely overlapping distribution ranges in eastern North America (Hipp and Weber 2008). Populations of Q. rubra, Q. ellipsoidalis and Q. velutina can be found in sympatry, but preferentially occur in different micro-environments with regard to water availability (Hipp and Weber 2008; Owusu et al. accepted). Thus, Querucs ellipsoidalis is considered as most droughttolerant species, followed by $Q$. coccinea, $Q$. velutina and $Q$. rubra as the most mesophilic species (Abrams 1990). Analyses at genomic and gene-based microsatellite markers between these population pairs revealed low interspecific differentiation at most nuclear markers, but high differentiation at a few outlier loci suggesting strong divergent selection (Sullivan et al. 2013; Lind-Riehl et al. 2014). Species identity was confirmed based on whole tree silvic and leaf morphological characters (Hipp and Weber 2008; Hipp et al. 2010) for all populations and by genetic assignment analysis at discriminative microsatellite markers for most populations (Hipp and Weber 2008; Lind and Gailing 2013; Lind-Riehl et al. 2014; Owusu et al. accepted). Specifically, morphological species identification was based on leaf, bud and acorn characteristics. For example, end buds are mainly hairless in $Q$. rubra, silky-pubescent in $Q$. ellipsoidalis and Q. coccinea and densely canescent in Q. velutina (Hipp and Weber 2008). Samples from the sympatric Q. rubra / Q. ellipsoidalis populations FCF-QR/FCF-QE and ES- 
125 QR/ES-QE were identified in the field only based on whole tree silvic characteristics and leaf

126 morphological characters that differentiate between both species (Gailing et al. 2012). For most

127 populations eight genetically identified samples (5 to 8 ) were randomly selected from each stand

128 for the cpDNA analyses (Table 1). Plant material for four populations (HNF-QR, ONF-QR,

129 ANF-QR and HMNF-QR) was derived from seed-grown seedlings obtained from the J. W.

130 Toumey Nursery (USDA Forest Service, Watersmeet, Michigan). Seeds were collected

131 randomly within populations.

132 Chloroplast DNA analyses

133 Total genomic DNA ( $20 \mathrm{ng})$ was isolated from fresh or silica gel dried leaf material following 134 the DNeasy96 Plant Kit protocol of Qiagen (Hilden, Germany). A total of ten consensus 135 chloroplast microsatellite primers (ccmps) developed for dicotyledonous angiosperms (Weising samples from eight geographically distant populations including all four species. Since cpDNA

139 alleles are jointly transmitted due to the absence of recombination (Finkeldey and Gailing 2013) corresponding haplotypes can be inferred at different sets of polymorphic markers. Thus, these chloroplast microsatellites have been applied earlier in European white oaks and distinguished 142 several chloroplast haplotypes that had been identified by PCR-RFLP (Gailing et al. 2009; Petit 143 et al. 2002a, b), and there was no indication of size homoplasy for these markers (Gailing et al. 1442007 a, b; Gailing et al. 2009). Nine markers generated amplification products, three of which 145 (ccmp2, ccmp4 and udt4) were found to be polymorphic, and were used to screen 287 samples 146 (5-8 individuals from each population). DNA was diluted (1:20) prior to PCR amplification. 147 PCR reactions were performed in the Applied Biosystems 2720 thermal cycler in a $15 \mu 1$ reaction 


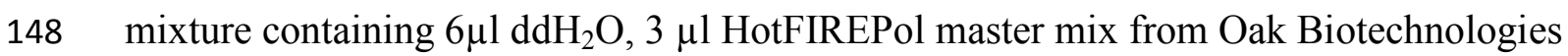

149 (containing $10 \mathrm{mM}$ Tris-HCL (pH 9.0), $10 \mathrm{mM} \mathrm{MgCl}_{2}, 2 \mathrm{mM}$ of each dNTP, 0.4U HOTFIREpol

150 Taq DNA polymerase), $2 \mu \mathrm{l}$ of each forward and reverse primer $(5 \mathrm{pmol} / \mu \mathrm{l})$ and $2 \mu 1$ of diluted

151 DNA (about $1 \mathrm{ng}$ ). The forward primers were labeled with the fluorescent dye 6-FAM. The PCR

152 profile for the three primers was $15 \mathrm{~min}$ initial denaturation at $95^{\circ} \mathrm{C}$, followed by 35 cycles of 45

$153 \mathrm{sec}$ denaturation at $94^{\circ} \mathrm{C}, 45 \mathrm{sec}$ annealing at $50^{\circ} \mathrm{C}$ and $1 \mathrm{~min}$ extension at $72^{\circ} \mathrm{C}$, with a final

154 extension of $10 \mathrm{~min}$ at $72^{\circ} \mathrm{C}$. The PCR products were tested on $2 \%$ agarose gels and then diluted

155 for genotyping on an ABI Prism Genetic Analyzer 3730 (Applied Biosystems) at Cornell

156 University. Fragments were scored using GeneMapper v.4.0 (Applied Biosystems).

\section{Data analyses}

158 Polymorphisms in fragment size were identified as different length variants that were combined

159 to define haplotypes (suppl. Fig. 1). Total haplotypic diversity and diversity within

160 populations/species was calculated as $\mathrm{H}_{\mathrm{T}}$ and $\mathrm{H}_{\mathrm{S}}$, and as $\mathrm{R}_{\mathrm{T}}$ and $\mathrm{R}_{\mathrm{S}}$ which take mutational

161 differences among haplotypes into account. Likewise genetic differentiation among populations

162 was computed as $\mathrm{G}_{\mathrm{ST}}$ and $\mathrm{R}_{\mathrm{ST}}$ with PermutcpSSR 2.0 (available at

163 http://www.pierroton.inra.fr/genetics/labo/Software/ PermutCpSSR/index.html) as described in

164 Pons and Petit (1995). Since only one population of $Q$. coccinea was analyzed, these samples

165 were excluded for the calculation of $\mathrm{G}_{\mathrm{ST}} / \mathrm{R}_{\mathrm{ST}}$ among species. Haplotype networks were created

166 with the program Network 4.6.1.2. (released January 1, 2014, http://www.fluxus-

167 engineering.com/netwinfo.htm) (Bandelt et al. 1995; Bandelt et al. 1999) using the reduced

168 median method. Specifically, the haplotype data were saved as *.ych file and run through star

169 contraction; the contracted data (saved as *.rdf file) were calculated with the reduced median

170 method and results were saved as *.sco file for network calculation. 
171 Results

172 Out of all cpSSRs tested the three markers ccmp2, ccmp4 and $u d t 4$ showed clear and

173 polymorphic amplification products (suppl. Fig. 2). Combining the observed fragment lengths at

174 these three markers, a total of 23 haplotypes were observed (suppl. Fig. 1), ten of which were

175 present in more than one sample (Table 1). Haplotype $1(\mathrm{H} 1)$ was the most frequent haplotype

176 overall (70.04\%) and for each species (Table 1, 2, Fig. 1). The closely related haplotype H2 was

177 rare in most populations, but was dominating in the easternmost Q. rubra population ANF-QR.

178 Also the other more frequent haplotypes were shared among at least two species (Table 2, Fig. 1,

179 2). For example, haplotype $\mathrm{H} 9$ was restricted to a single geographic region (OF) and was shared

180 between a neighboring Q. ellipsoidalis / Q. velutina population pair (Table 1, Fig. 1). As a

181 general pattern, neighboring interspecific population pairs shared haplotypes, strongly suggesting

182 contemporary interspecific gene flow (Fig. 1). As a consequence genetic differentiation among

183 the species $Q$. rubra, Q. ellipsoidalis and $Q$. velutina was very low $\left(\mathrm{G}_{\mathrm{ST}}=0.023, \mathrm{R}_{\mathrm{ST}}=0.016\right)$,

184 while much higher genetic differentiation was found among all populations $\left(\mathrm{G}_{\mathrm{ST}}=0.277, \mathrm{R}_{\mathrm{ST}}=\right.$ 185 0.329). Haplotypic diversity within populations was comparatively high for each species (Table

$1863,4)$. Within species the highest differentiation among populations was observed for Q. velutina

$187\left(\mathrm{G}_{\mathrm{ST}}=0.5771, \mathrm{R}_{\mathrm{ST}}=0.5709\right)$ as two out of the five populations were fixed for $\mathrm{H} 1$ and two other

188 populations showed a high frequency of two other haplotypes with restricted geographic

189 distribution shared with the neighboring Q. ellipsoidalis populations (Fig. 1). The genetic

190 differentiation between $Q$. rubra $\left(\mathrm{G}_{\mathrm{ST}}=0.206, \mathrm{R}_{\mathrm{ST}}=0.253\right)$ and Q. ellipsoidalis $\left(\mathrm{G}_{\mathrm{ST}}=0.240\right.$,

$\left.191 \mathrm{R}_{\mathrm{ST}}=0.301\right)$ populations was comparatively low. Private haplotypes were present in $Q$. rubra, $Q$.

192 ellipsoidalis and Q. velutina, but occurred mostly in single individuals (Table 2). Overall the

193 genetic differentiation between populations at cpDNA markers confirmed earlier observations of 
194 a comparatively weak phylogeographic pattern. Among Q. rubra populations, only populations

195 ANF-QR and N-QR did not show H1 as predominant haplotype. Since our sampling was not 196 range-wide for any of the three species and the number of populations for each species was

197 different, variation estimates within and among species are representative for our sampling and 198 might vary in other parts of the species' range.

\section{Discussion}

\section{Haplotype diversity}

201 While most samples were collected from adult trees in natural stands subjected to no or limited 202 management, population ES-QR was collected close to a campground, and the high haplotype 203 diversity and occurrence of rare haplotypes in this population suggests that at least some of the 204 trees were planted. For populations HNF-QR, ONF-QR, ANF-QR and HMNF-QR seed-grown 205 seedlings were obtained from a nursery and mixing of reproductive material from different stands within one region was not excluded. However, only one population (ONF-QR) showed a

207 high haplotype diversity which might indicate mixing of reproductive material.

208 The weak phylogeographic pattern found in the present study confirmed earlier results of PCRRFLP analyses of cpDNA variation of 66 Q. rubra populations collected throughout the species' range (Magni et al. 2005). Similar to our multispecies study, a star-like phylogenetic network

211 was derived with one predominating haplotype occurring in $\sim 75 \%$ of the samples $(\sim 70 \%$ in the

212 present study). While our sampling was intensive in the Upper Midwest and focused on

213 interspecific populations pairs, the earlier Q. rubra study had a stronger representation of eastern 214 populations. Population differentiation in the latter study $\left(\mathrm{G}_{\mathrm{ST}}=0.46\right)$ and in the present study

215 was comparatively low $\left(Q\right.$. rubra, $\mathrm{G}_{\mathrm{ST}}=0.206 ;$ Q ellipsoidalis, $\mathrm{G}_{\mathrm{ST}}=0.243 ;$ Q velutina, $\mathrm{G}_{\mathrm{ST}}=$ 
216 0.558). Likewise, cpDNA analyses in the northwestern section of the range showed moderate

217 levels of population differentiation $\left(\mathrm{G}_{\mathrm{ST}}=0.58\right)$ in $Q$. rubra (Birchenko et al. 2009) displaying

218 the highest differentiation values in the southeastern part of the sampling area (Romero-Severson

219 et al. 2003). The overall low differentiation at cpDNA markers was attributed to the relatively

220 large area without major geographical barriers occupied by $Q$. rubra forests during the Last

221 Glacial Maximum (LGM) in North America, with some populations reaching far north close to

222 the glacial margin (Williams 2002; Magni et al. 2005). The existence of one major distribution

223 range during the LGM might have provided only restricted opportunities for northward migration

224 (only a few hundred kilometers) and for long distance founder events (Magni et al. 2005). On the

225 other hand, geographic isolation of refugia and resulting genetic drift might have resulted in new

226 cpDNA lineages and high genetic differentiation among populations from different refugia in

227 Europe (Petit et. 2003a). European white oak populations re-colonized the tundra-like, treeless

228 landscape of central and northern Europe from three discrete glacial refugia, the Iberian and

229 Italian Peninsulas and the Balkans, with distinct chloroplast lineages as reflected in strong

230 cpDNA differentiation among geographic regions (Petit et al. 2002a; Petit et al. 2002b; Petit et

231 al. 2003a). Likewise, the contemporary distribution of cpDNA haplotypes suggested long

232 distance seed dispersal and founder events that resulted in today's strong genetic differentiation

233 at cpDNA markers among populations (Petit et al. 2002a; Petit et al. 2002b; Petit et al. 2003a). In

234 summary, since European white oaks and North American red oaks show similar life history

235 traits, differences in genetic structure at cpDNA markers could have been affected by the

236 isolation among refugia, different opportunities for northward migration and long distance seed

237 dispersal after the Last Glacial Maximum, by interspecific gene flow and by different topologies

238 in Europe and North America (Magni et al. 2005; Petit et al. 2003a). 


\section{Sharing of chloroplast haplotypes among species}

240

241

242

243

244

245

246

247

248

249

250

251

252

253

254

255

256

257

258

259

260

261

Similar to interfertile European white oaks (Petit et al. 2003b), no significant differentiation among the red oak species was detectable at cpDNA markers. Low genetic differentiation can be the result of ancestral polymorphism shared among species (Muir and Schlötterer 2005), even in the absence of gene flow, or the outcome of contemporary interspecific gene flow. Our results provide clear evidence for contemporary gene flow between species. Thus, all haplotypes (with a frequency larger than two) were shared among at least two species, and most haplotypes were shared among the three species Q. rubra, Q. ellipsoidalis and Q. velutina. The only population of Q. coccinea shared H1 with all other species and the other haplotype, H4, with Q. rubra. The sharing of haplotypes (see Fig. 2) among species and differentiation among populations from different geographic regions strongly suggested recurrent interspecific gene flow. Additionally, both frequent and regional haplotypes were shared between species in sympatric and neighboring stands. Thus, regional haplotypes with restricted geographic distribution H9 (region OF) was shared between Q. ellipsoidalis / Q. velutina, and $\mathrm{H} 7$ was shared between $Q$. rubra / $Q$. ellipsoidalis (region NN) and Q. velutina / Q. ellipsoidalis (region WR). The sharing of haplotypes with restricted geographic distribution between these neighboring stands provides conclusive evidence for interspecific gene flow.

Interspecific gene flow between interfertile red oak species was also reflected in very low interspecific differentiation among the red oak species Q. rubra, Q. ellipsoidalis, Q. velutina and Q. coccinea at most nuclear DNA markers (Sullivan et al. 2013) and a pattern of genomic divergence consistent with the maintenance of species integrity in the face of gene flow by divergent selection in neighboring Q. rubra / Q. ellipsoidalis (Lind-Riehl et al. 2014) and $Q$. velutina / Q. ellipsoidalis populations (Sullivan 2013; Sullivan et al. submitted). Genomic 
262 signatures of divergent selection in the red oaks (Sullivan et al. 2013; Lind-Riehl et al. 2014) and

263 the European white oaks (Goicoechea et al. 2012, 2015) between co-occurring interfertile species

264 with different local adaptations suggests that oaks in general are models to study the genomic

265 basis of speciation and maintenance of species integrity with gene flow.

\section{Outlook}

267 The sharing of cpDNA haplotypes was expected according to the model of maintenance of 268 species integrity with gene flow by divergent selection. The availability of genetic linkage maps

269 in Q. rubra (unpublished results) and in Q. robur (Bodénès et al. 2012; Gailing et al. 2013) and 270 of a genome sequence in Q. robur (Plomion et al. 2015) will allow us to compare the genomic 271 distribution of regions under divergent selection across taxonomic sections.

\section{Acknowledgements}

273 We would like to thank the Hanes Trust, the Huron Mountain Wildlife Foundation and the

274 Research Excellence fund of Michigan Technological University (MTU) for their financial 275 support. Additional support came from MTU's Biotech Research Center and Ecosystem Science

276 Center. We are also thankful to Anthony Holland and Christine Makuck of the J.W. Toumey

277 nursery for providing seed material for four of the populations. Dr. Ruhua Zhang was supported

278 by a scholarship for international co-operation and training of outstanding young and middle-age 279 teachers launched by the Education Department of Shandong Province. 


\section{References}

Abbott, R., Albach, D., Ansell, S., Arntzen, J.W., Baird, S.J.E., Bierne, N., Boughman, J., Brelsford, A., Buerkle, C.A., Buggs, R., Butlin, R.K., Dieckmann, U., Eroukhmanoff, F., Grill, A., Cahan, S.H., Hermansen, J.S., Hewitt, G., Hudson, A.G., Jiggins, C., Jones, J., Keller, B., Marczewski, T., Mallet, J., Martinez-Rodriguez, P., Möst, M., Mullen, S., Nichols, R., Nolte, A.W., Parisod, C., Pfennig, K., Rice, A.M., Ritchie, M.G., Seifert, B., Smadja, C.M., Stelkens, R., Szymura, J.M., Väinölä, R., Wolf, J.B.W., and Zinner, D. 2013. Hybridization and speciation. J. Evol. Biol. 26: 229-246.

Abrams, M.D. 1990. Adaptations and responses to drought in Quercus species of NorthAmerica. Tree Physiology 7: 227-238.

Abrams, M.D. 1992. Fire and the development of oak forests in eastern North America, oak distribution reflects a variety of ecological paths and disturbance conditions. Bioscience 42: 346-353.

Alberto, F.J., Derory, J., Boury, C., Frigerio, J.M., Zimmermann, N.E., and Kremer, A. 2013. Imprints of natural selection along environmental gradients in phenology-related genes of Quercus petraea. Genetics 195: 495-512.

Arnold, M.L. 2004. Transfer and origin of adaptations through natural hybridization: Were Anderson and Stebbins right? Plant Cell 16: 562-570.

Arnold, M.L., and Martin, N.H. 2011. Hybrid fitness across time and habitats. Trends in Ecology \& Evolution 25: 530-536.

Bandelt, H.J., Forster, P., and Rohl, A. 1999. Median-joining networks for inferring intraspecific phylogenies. Molecular Biology and Evolution 16: 37-48.

Bandelt, H.J., Forster, P., Sykes, B.C., and Richards, M.B. 1995. Mitochondrial portraits of human populations using median networks. Genetics 141: 743-753. 
304 305

306

307

308

309

310

311

312

313

314

315

316

317

318

319

320

321

322

323

324

Birchenko, I., Feng, Y., and Romero-Severson, J. 2009. Biogeographical distribution of chloroplast diversity in Northern red oak (Quercus rubra L.). American Midland Naturalist 161: 134-145.

Bodénès, C., Chancerel, E., Gailing, O., Vendramin, G.G., Bagnoli, F., Durand, J., Goicoechea, P.G., Soliani, C., Villani, F., Mattioni, C., Koelewijn, H.P., Murat, F., Salse, J., Roussel, G., Boury, C., Alberto, F., Kremer, A., and Plomion, C. 2012. Comparative mapping in the Fagaceae and beyond with EST-SSRs. BMC Plant Biol. 12: 153.

Brendel, O., Le Thiec, D., Scotti-Saintagne, C., Bodenes, C., Kremer, A., and Guehl, J.-M. 2008. Quantitative Trait loci controlling water use efficiency and related traits in Quercus robur L. Tree Genet. Genomes 4: 263-278.

Collins, E., Sullivan, A., and Gailing, O. 2015. Limited effective gene flow between two interfertile red oak species. Trees-Structure and Function 29:1135-1148.

Curtu, A.L., Gailing, O., and Finkeldey, R. 2007. Evidence for hybridization and introgression within a species-rich oak (Quercus spp.) community. BMC Evolutionary Biology 7: 218.

Curtu, A.L., Gailing, O., and Finkeldey, R. 2009. Patterns of contemporary hybridization inferred from paternity analysis in a four-oak-species forest. BMC Evolutionary Biology 9: 284 .

de Heredia, U.L., Valbuena-Carabana, M., Cordoba, M., and Gil, L. 2009. Variation components in leaf morphology of recruits of two hybridising oaks $Q$. petraea (Matt.) Liebl. and $Q$. pyrenaica Willd. at small spatial scale. European Journal of Forest Research 128: 543554. 
325 Deguilloux, M.-F., Dumolin-Lapegue, S., Gielly, L., Grivet, D., and Petit, R.J. 2003. A set of

326

327

328

329

330

331

332

333

334

335

336

337

338

339

340

341

342

343

344

345

346 primers for the amplification of chloroplast microsatellites in Quercus. Mol. Ecol. Notes 3: $24-27$.

Dodd, R.S., and Afzal-Rafii, Z. 2004. Selection and dispersal in a multispecies oak hybrid zone. Evolution 58: 261-269.

Finkeldey, R., and Gailing, O. 2013. Genetics of chloroplasts. Pages 525-527 in S. Maloy and K. Hughes, editors. Brenner‘s Encyclopedia of Genetics. Elsevier.

Gailing, O. 2014. Strategies to identify adaptive genes in hybridizing trees like oaks and poplars. Not. Bot. Horti Agrobot. Cluj-Na. 42: 299-309.

Gailing, O., and Curtu, A.L. 2014. Interspecific gene flow and maintenance of species integrity in oaks. Annals of Forest Research 57: 5-18.

Gailing, O., Wachter, H., Heyder, J., Schmittz, H.P., and Finkeldey, R. 2007a. Chloroplast DNA analysis in oak stands (Quercus robur L.) in North Rhine-Westphalia with presumably Slavonian origin: Is there an association between geographic origin and bud phenology? Journal of Applied Botany and Food Quality-Angewandte Botanik 81: 165-171.

Gailing, O., Wachter, H., Schmitt, H.P., Curtu, A.L., and Finkeldey, R. 2007b. Characterization of different provenances of Slavonian pedunculate oaks (Quercus robur L.) in Münsterland (Germany) with chloroplast DNA markers: PCR-RFLPs and chloroplast microsatellites. Allgemeine Forst und Jagdzeitung 178: 85-90.

Gailing, O., Wachter, H., Heyder, J., Rogge, M., and Finkeldey, R. 2009. Chloroplast DNA analyses of very old, presumably autochthonous Quercus robur L. stands in North RhineWestphalia. Allgemeine Forst und Jagdzeitung 180: 221-227. 
347 Gailing, O., Lind, J., and Lilleskov, E.A. 2012. Leaf morphological and genetic differentiation

348

349

350

351

352

353

354

355

356

357

358

359

360

361

362

363

364

365

366

367

368

between Quercus rubra L. and Q. elliposidalis E. J. Hill populations in contrasting environments. Plant Syst. Evol. 298: 1533-1545.

Gailing, O., Bodénès, C., Finkeldey, R., Kremer, A., and Plomion, C. 2013. Genetic mapping of EST-derived Simple Sequence Repeats (EST-SSRs) to identify QTL for leaf morphological characters in a Quercus robur full-sib family. Tree Genet. Genomes 9: 1361-1367.

Goicoechea, P.G., Petit, R.J., and Kremer, A. 2012. Detecting the footprints of divergent selection in oaks with linked markers. Heredity 109: 361-371.

Goicoechea, P.G., Herran, A., Durand, J., Bodénès, C., Plomion, C., and Kremer, A. 2015. A linkage disequilibrium perspective on the genetic mosaic of speciation in two hybridizing Mediterranean white oaks. Heredity 114: 373-386.

Herrmann, D., Barre, P., Santoni, S., and Julier, B. 2010. Association of a CONSTANS-LIKE gene to flowering and height in autotetraploid alfalfa. Theor. Appl. Genet. 121: 865-876.

Heuertz, M., Fineschi, S., Anzidei, M., Pastorelli, R., Salvini, D., Paule, L., Frascaria-Lacoste, N., Hardy, O.J., Vekemans, X., and Vendramin, G.G. 2004. Chloroplast DNA variation and postglacial recolonization of common ash (Fraxinus excelsior L.) in Europe. Mol. Ecol. 13: 3437-3452.

Hipp, A.L., and Weber, J.A. 2008. Taxonomy of Hill's oak (Quercus ellipsoidalis: Fagaceae): Evidence from AFLP data. Syst. Bot. 33: 148-158.

Hipp, A.L., Weber, J.A., and Srivastava, A. 2010. Who am I this time? The affinities and misbehaviors of Hill's oak (Quercus ellipsoidalis). International Oak Journal 21: 27-36. 
Hsu, C.Y., Adams, J.P., No, K., Liang, H.Y., Meilan, R., Pechanova, O., Barakat, A., Carlson, J.E., Page, G.P., and Yuceer, C. 2012. Overexpression of Constans homologs CO1 and $\mathrm{CO} 2$ fails to alter normal reproductive onset and fall bud set in woody perennial poplar. PLoS One 7.

Levy, G., Becker, M., and Duhamel, D. 1992. A comparison of the ecology of pedunculate and sessile oaks - radial growth in the center and northwest of France. For. Ecol. Manage. 55: $51-63$.

Lind-Riehl, J., Sullivan, A., and Gailing, O. 2014. Evidence for selection on a CONSTANS-like gene between two red oak species. Ann. Bot. 113: 967-975.

Lind, J., and Gailing, O. 2013. Genetic structure of Quercus rubra L. and Q. ellipsoidalis E. J. Hill populations at gene-based EST-SSR and nuclear SSR markers. Tree Genet. Genomes 31: 231-239.

Magni, C.R., Ducousso, A., Caron, H., Petit, R.J., and Kremer, A. 2005. Chloroplast DNA variation of Quercus rubra L. in North America and comparison with other Fagaceae. Mol. Ecol. 14: 513-524.

Muir, G., and Schlötterer, C. 2005. Evidence for shared ancestral polymorphism rather than recurrent gene flow at microsatellite loci differentiating two hybridising oaks (Quercus spp.). Mol. Ecol. 14: 549-561.

Nevill, P.G., Despres, T., Bayly, M.J., Bossinger, G., and Ades, P.K. 2014. Shared phylogeographic patterns and widespread chloroplast haplotype sharing in Eucalyptus species with different ecological tolerances. Tree Genet. Genomes 10: 1079-1092.

Owusu, S.A., Sullivan, A.R., Weber, J.A., Hipp, A.L., and Gailing, O. in press. Taxonomic relationships and gene flow in four North American Quercus species. Syst. Bot. 
392 393 394 395 396 397 398 399 400 401 402 403 404 405 406 407 408 409 410

Palmé, A.E., Su, Q., Rautenberg, A., Manni, F., and Lascoux, M. 2003. Postglacial recolonization and cpDNA variation of silver birch, Betula pendula. Mol. Ecol. 12: 201212.

Palmé, A.E., Su, Q., Palsson, S., and Lascoux, M. 2004. Extensive sharing of chloroplast haplotypes among European birches indicates hybridization among Betula pendula, $B$. pubescens and B. nana. Mol. Ecol. 13: 167-178.

Petit, R., Aguinagalde, I., Beaulieu, J., Bittkau, C., Brewer, S., Cheddadi, R., Ennos, R., Fineschi, S., Grivet, D., Lascoux, M., Mohanty, A., Müller-Starck, G., Demesure-Musch, B., Palmé, A., Martín, J.P., Rendell, S., and Vendramin, G.G. 2003a. Glacial refugia: Hotspots but not melting pots of genetic diversity. Science 300: 1563-1565.

Petit, R., Brewer, S., Bordács, S., Burg, K., Cheddadi, R., Coart, E., Cottrell, J., Csaikl, U., van Dam, B., Deans, D., Espinel, S., Fineschi, S., Finkeldey, R., Glaz, I., Goicoechea, P.G., Jensen, J.S., König, A.O., Lowe, A.J., Madsen, S.F., Mátyás, G., Munro, R.C., Popescu, F., Slade, D., Tabbener, H., de Vries, S.G.M., Ziegenhagen, B., de Beaulieu, J.-L., and Kremer, A. 2002a. Identification of refugia and post-glacial colonisation routes of European white oaks based on chloroplast DNA and fossil pollen evidence. For. Ecol. Manage. 156: 49-74.

Petit, R., Csaikl, U., Bordács, S., Burg, K., Coart, E., Cottrell, J., van Dam, B., Deans, D., Dumolin-Lapègue, S., Fineschi, S., Finkeldey, R., Gillies, A., Glaz, I., Goicoechea, P.G., Jensen, J.S., König, A.O., Lowe, A.J., Madsen, S.F., Mátyás, G., Munro, R.C., Olalde, M., Pemonge, M.-H., Popescu, F., Slade, D., Tabbener, H., Taurchini, D., de Vries, S.G.M., Ziegenhagen, B., and Kremer, A. 2002b. Chloroplast DNA variation in European 
white oaks. Phylogeography and patterns of diversity based on data from over 2600 populations. For. Ecol. Manage. 156: 5-26.

Petit, R.J., Bodenes, C., Ducousso, A., Roussel, G., and Kremer, A. 2003b. Hybridization as a mechanism of invasion in oaks. New Phytol. 161: 151-164.

Plomion, C., Aury, J.-M., Amselem, J., Alaeitabar, T., Barbe, V., Belser, C., Bergès, H., Bodénès, C., Boudet, N., Boury, C., Canaguier, A., Couloux, A., Da Silva, C., Duplessis, S., Ehrenmann, F., Estrada-Mairey, B., Fouteau, S., Francillonne, N., Gaspin, C., Guichard, C., Klopp, C., Labadie, K., Lalanne, C., Le Clainche, I., Leplé, J.-C., Le Provost, G., Leroy, T., Lesur, I., Martin, F., Mercier, J., Michotey, C., Murat, F., Salin, F., Steinbach, D., Faivre-Rampant, P., Wincker, P., Salse, J., Quesneville, H., and Kremer, A. 2015. Decoding the oak genome: public release of sequence data, assembly, annotation and publication strategies. Mol. Ecol. Resour.: DOI:10.1111/1755-0998.12425

Pons, O., and Petit, R.J. 1995. Estimation, variance and optimal sampling of gene diversity. I. Haploid locus. Theor. Appl. Genet. 90: 462-470.

Romero-Severson, J., Aldrich, P., Feng, Y., Sun, W.L., and Michler, A. 2003. Chloroplast DNA variation of northern red oak (Quercus rubra L.) in Indiana. New Forests 26: 43-49.

Rushton, B.S. 1993. Natural hybridization within the genus Quercus. Ann. Sci. For. 50: 73s-90s.

Scotti-Saintagne, C., Mariette, S., Porth, I., Goicoechea, P.G., Barreneche, T., Bodenes, C., Burg, K., and Kremer, A. 2004. Genome scanning of interspecific differentiation between two closely related oak species (Quercus robur L. and Q. petraea (Matt.) Liebl.). Genetics 168: $1615-1626$.

Seehausen, O., Butlin, R.K., Keller, I., Wagner, C.E., Boughman, J.W., Hohenlohe, P.A., Peichel, C.L., Saetre, G.P., Bank, C., Brannstrom, A., Brelsford, A., Clarkson, C.S., 
437

438

439

440

441

442

443

444

445

446

447

448

449

450

451

452

453

454

455

456

457

458

Eroukhmanoff, F., Feder, J.L., Fischer, M.C., Foote, A.D., Franchini, P., Jiggins, C.D., Jones, F.C., Lindholm, A.K., Lucek, K., Maan, M.E., Marques, D.A., Martin, S.H., Matthews, B., Meier, J.I., Most, M., Nachman, M.W., Nonaka, E., Rennison, D.J., Schwarzer, J., Watson, E.T., Westram, A.M., and Widmer, A. 2014. Genomics and the origin of species. Nature Reviews Genetics 15: 176-192.

Strasburg, J.L., Sherman, N.A., Wright, K.M., Moyle, L.C., Willis, J.H., and Rieseberg, L.H. 2012. What can patterns of differentiation across plant genomes tell us about adaptation and speciation? Philos. Trans. R. Soc. B-Biol. Sci. 367: 364-373.

Sullivan, A. 2013. Speciation with gene-flow in eastern North American red oaks (Quercus section Lobatae). Michigan Technological UniversityHoughton, Michigan.

Sullivan, A., Lind, J., McCleary, T.S., Romero-Severson, J., and Gailing, O. 2013. Development and characterization of genomic and gene-based microsatellite markers in North American red oak species. Plant Molecular Biology Reporter 31: 231-239.

Via, S. 2009. Natural selection in action during speciation. Proc. Natl. Acad. Sci. U. S. A. 106: 9939-9946.

Via, S. 2012. Divergence hitchhiking and the spread of genomic isolation during ecological speciation-with-gene-flow. Philos. Trans. R. Soc. B-Biol. Sci. 367: 451-460.

Via, S., and West, J. 2008. The genetic mosaic suggests a new role for hitchhiking in ecological speciation. Mol. Ecol. 17: 4334-4345.

Weising, K., and Gardner, R.C. 1999. A set of conserved PCR primers for the analysis of simple sequence repeat polymorphisms in chloroplast genomes of dicotyledonous angiosperms. Genome 42: 9-19. 
459 Williams, J.W. 2003. Variations in tree cover in North America since the last glacial maximum. $460 \quad$ Global and Planetary Change 35: 1-23.

461 Yano, M., Katayose, Y., Ashikari, M., Yamanouchi, U., Monna, L., Fuse, T., Baba, T., 462 Yamamoto, K., Umehara, Y., Nagamura, Y., and Sasaki, T. 2000. Hd1, a major 463 photoperiod sensitivity quantitative trait locus in rice, is closely related to the Arabidopsis 464 flowering time gene CONSTANS. Plant Cell 12: 2473-2483. 
Table 1. Sample locations and haplotype frequencies

\begin{tabular}{|c|c|c|c|c|c|c|c|c|c|c|c|c|c|c|c|}
\hline \multirow[b]{2}{*}{ abbreviation } & \multirow[b]{2}{*}{ region } & \multirow[b]{2}{*}{ species } & \multirow[b]{2}{*}{$\mathrm{N}$} & \multirow[b]{2}{*}{ latitude } & \multirow[b]{2}{*}{ longitude } & \multicolumn{10}{|c|}{ haplotype frequencies } \\
\hline & & & & & & 1 & 2 & 3 & 4 & 5 & 6 & 7 & 9 & 16 & 19 \\
\hline FCA-QR & $\mathrm{FC}$ & Q. rubra & 8 & $46^{\circ} 39^{\prime} 09^{\prime \prime} \mathrm{N}$ & $88^{\circ} 30^{\prime} 07^{\prime \prime} \mathrm{W}$ & 7 & 0 & 0 & 0 & 0 & 0 & 0 & 0 & 0 & 0 \\
\hline FCB-QR & $\mathrm{FC}$ & Q. rubra & 8 & $46^{\circ} 40^{\prime} 28^{\prime \prime} \mathrm{N}$ & $88^{\circ} 31^{\prime} 27^{\prime \prime} \mathrm{W}$ & 7 & 0 & 0 & 0 & 0 & 0 & 0 & 0 & 0 & 0 \\
\hline FCC-QE & $\mathrm{FC}$ & Q. ellipsoidalis & 8 & $46^{\circ} 39^{\prime} 14^{\prime \prime} \mathrm{N}$ & $88^{\circ} 35^{\prime} 26^{\prime \prime} \mathrm{W}$ & 7 & 0 & 1 & 0 & 0 & 0 & 0 & 0 & 0 & 0 \\
\hline FCE-QE & $\mathrm{FC}$ & Q. ellipsoidalis & 8 & $46^{\circ} 39^{\prime} 56^{\prime \prime} \mathrm{N}$ & $88^{\circ} 33^{\prime} 20^{\prime \prime} \mathrm{W}$ & 6 & 0 & 0 & 0 & 2 & 0 & 0 & 0 & 0 & 0 \\
\hline FCF-QR & $\mathrm{FC}$ & Q. rubra & 8 & $46^{\circ} 40^{\prime} 29^{\prime \prime} \mathrm{N}$ & $88^{\circ} 32^{\prime} 06^{\prime \prime} \mathrm{W}$ & 7 & 0 & 0 & 0 & 0 & 0 & 0 & 0 & 0 & 0 \\
\hline FCF-QE & $\mathrm{FC}$ & Q. ellipsoidalis & 8 & $46^{\circ} 40^{\prime} 29^{\prime \prime} \mathrm{N}$ & $88^{\circ} 32^{\prime} 06^{\prime \prime} \mathrm{W}$ & 6 & 0 & 0 & 0 & 0 & 2 & 0 & 0 & 0 & 0 \\
\hline ES-QR & ES & Q. rubra & 8 & $45^{\circ} 04^{\prime} 01^{\prime \prime} \mathrm{N}$ & $86^{\circ} 59^{\prime} 38^{\prime \prime} \mathrm{W}$ & 3 & 0 & 0 & 1 & 2 & 1 & 0 & 0 & 0 & 0 \\
\hline ES-QE & ES & Q. ellipsoidalis & 8 & $45^{\circ} 04^{\prime} 01^{\prime \prime} \mathrm{N}$ & $86^{\circ} 59^{\prime} 38^{\prime \prime} \mathrm{W}$ & 6 & 1 & 0 & 0 & 0 & 0 & 0 & 0 & 0 & 0 \\
\hline $\mathrm{N}-\mathrm{QR}$ & $\mathrm{NN}$ & Q. rubra & 8 & $45^{\circ} 20^{\prime} 53^{\prime \prime} \mathrm{N}$ & $88^{\circ} 23^{\prime} 17^{\prime \prime} \mathrm{W}$ & 3 & 0 & 0 & 0 & 0 & 0 & 4 & 0 & 0 & 0 \\
\hline $\mathrm{N}-\mathrm{QE}$ & $\mathrm{NN}$ & Q. ellipsoidalis & 8 & $45^{\circ} 19^{\prime} 19^{\prime \prime} \mathrm{N}$ & $88^{\circ} 19^{\prime} 53^{\prime \prime} \mathrm{W}$ & 2 & 0 & 0 & 0 & 0 & 0 & 4 & 1 & 0 & 1 \\
\hline C-QR & $\mathrm{CN}$ & Q. rubra & 8 & $46^{\circ} 42^{\prime} 54^{\prime \prime} \mathrm{N}$ & $91^{\circ} 02^{\prime} 08^{\prime \prime} \mathrm{W}$ & 8 & 0 & 0 & 0 & 0 & 0 & 0 & 0 & 0 & 0 \\
\hline $\mathrm{C}-\mathrm{QE}$ & $\mathrm{CN}$ & Q. ellipsoidalis & 8 & $46^{\circ} 44^{\prime} 43^{\prime \prime} \mathrm{N}$ & $91^{\circ} 04^{\prime} 20^{\prime \prime} \mathrm{W}$ & 8 & 0 & 0 & 0 & 0 & 0 & 0 & 0 & 0 & 0 \\
\hline $\mathrm{W}-\mathrm{QE}$ & WR & Q. ellipsoidalis & 8 & $41^{\circ} 04^{\prime} 03^{\prime \prime} \mathrm{N}$ & $87^{\circ} 54^{\prime} 10^{\prime \prime} \mathrm{W}$ & 4 & 1 & 0 & 0 & 0 & 0 & 3 & 0 & 0 & 0 \\
\hline W-QV & WR & Q. velutina & 8 & $41^{\circ} 04^{\prime} 03^{\prime \prime} \mathrm{N}$ & $87^{\circ} 54^{\prime} 10^{\prime \prime} \mathrm{W}$ & 0 & 0 & 0 & 0 & 0 & 0 & 7 & 0 & 0 & 0 \\
\hline $\mathrm{O}-\mathrm{QE}$ & OF & Q. ellipsoidalis & 8 & $44^{\circ} 26^{\prime} 59^{\prime \prime} \mathrm{N}$ & $84^{\circ} 12^{\prime} 04^{\prime \prime} \mathrm{W}$ & 2 & 0 & 1 & 0 & 0 & 0 & 0 & 5 & 0 & 0 \\
\hline $\mathrm{O}-\mathrm{QV}$ & $\mathrm{OF}$ & Q. velutina & 8 & $44^{\circ} 26^{\prime} 59^{\prime \prime} \mathrm{N}$ & $84^{\circ} 12^{\prime} 04^{\prime \prime} \mathrm{W}$ & 2 & 0 & 0 & 0 & 0 & 0 & 0 & 5 & 0 & 0 \\
\hline $\mathrm{R}-\mathrm{QE}$ & $\mathrm{RE}$ & Q. ellipsoidalis & 5 & $44^{\circ} 40^{\prime} 06^{\prime \prime} \mathrm{N}$ & $88^{\circ} 05^{\prime} 28^{\prime \prime} \mathrm{W}$ & 5 & 0 & 0 & 0 & 0 & 0 & 0 & 0 & 0 & 0 \\
\hline
\end{tabular}




\begin{tabular}{|c|c|c|c|c|c|c|c|c|c|c|c|c|c|c|c|}
\hline $\mathrm{R}-\mathrm{QV}$ & $\mathrm{RE}$ & Q. velutina & 5 & $44^{\circ} 40^{\prime} 06^{\prime \prime} \mathrm{N}$ & $88^{\circ} 05^{\prime} 28^{\prime \prime} \mathrm{W}$ & 5 & 0 & 0 & 0 & 0 & 0 & 0 & 0 & 0 & 0 \\
\hline $\mathrm{N}-\mathrm{QE}$ & $\mathrm{NE}$ & Q. ellipsoidalis & 8 & $43^{\circ} 02^{\prime} 11 " \mathrm{~N}$ & $85^{\circ} 48^{\prime} 00^{\prime \prime} \mathrm{W}$ & 8 & 0 & 0 & 0 & 0 & 0 & 0 & 0 & 0 & 0 \\
\hline N-QV & $\mathrm{NE}$ & Q. velutina & 8 & $43^{\circ} 02^{\prime} 11 " \mathrm{~N}$ & $85^{\circ} 48^{\prime} 00^{\prime \prime} \mathrm{W}$ & 8 & 0 & 0 & 0 & 0 & 0 & 0 & 0 & 0 & 0 \\
\hline $\mathrm{H}-\mathrm{QE}$ & HP & Q. ellipsoidalis & 8 & $41^{\circ} 31^{\prime} 35^{\prime \prime} \mathrm{N}$ & $87^{\circ} 26^{\prime} 35^{\prime \prime} \mathrm{W}$ & 3 & 1 & 0 & 0 & 2 & 0 & 0 & 0 & 0 & 0 \\
\hline H-QV & HP & Q. velutina & 8 & $41^{\circ} 31^{\prime} 35^{\prime \prime} \mathrm{N}$ & $87^{\circ} 26^{\prime} 35^{\prime \prime} \mathrm{W}$ & 5 & 1 & 0 & 0 & 1 & 1 & 0 & 0 & 0 & 0 \\
\hline HMR-PL & HMR & Q. rubra & 8 & $46^{\circ} 53^{\prime} 19^{\prime \prime} \mathrm{N}$ & $87^{\circ} 52^{\prime} 04^{\prime \prime W}$ & 8 & 0 & 0 & 0 & 0 & 0 & 0 & 0 & 0 & 0 \\
\hline HMR-MI & HMR & Q. rubra & 8 & $46^{\circ} 51^{\prime} 21 " \mathrm{~N}$ & $87^{\circ} 51^{\prime 2} 24^{\prime W}$ & 7 & 0 & 0 & 0 & 0 & 0 & 0 & 0 & 0 & 0 \\
\hline HMR-LI & HMR & Q. rubra & 8 & $46^{\circ} 04^{\prime} 39^{\prime \prime} \mathrm{N}$ & $87^{\circ} 51^{\prime} 18^{\prime \prime W}$ & 8 & 0 & 0 & 0 & 0 & 0 & 0 & 0 & 0 & 0 \\
\hline HMR-LP & HMR & Q. rubra & 7 & $46^{\circ} 51^{\prime} 00^{\prime \prime} \mathrm{N}$ & $87^{\circ} 49^{\prime} 49^{\prime \prime} \mathrm{W}$ & 6 & 1 & 0 & 0 & 0 & 0 & 0 & 0 & 0 & 0 \\
\hline HMR-IH & HMR & Q. rubra & 8 & $46^{\circ} 51^{\prime} 13^{\prime \prime} \mathrm{N}$ & $87^{\circ} 04^{\prime} 43^{\prime \prime W}$ & 4 & 0 & 0 & 0 & 4 & 0 & 0 & 0 & 0 & 0 \\
\hline HNF-QR & HNF & Q. rubra & 8 & $46^{\circ} 13^{\prime} 58^{\prime \prime} \mathrm{N}$ & $86^{\circ} 30^{\prime} 36^{\prime \prime} \mathrm{W}$ & 6 & 2 & 0 & 0 & 0 & 0 & 0 & 0 & 0 & 0 \\
\hline ONF-QR & ONF & Q. rubra & 8 & $46^{\circ} 13^{\prime} 48^{\prime \prime} \mathrm{N}$ & $88^{\circ} 57^{\prime} 00^{\prime \prime} \mathrm{W}$ & 2 & 1 & 1 & 0 & 1 & 0 & 2 & 0 & 1 & 0 \\
\hline ANF-QR & ANF & Q. rubra & 8 & $41^{\circ} 38^{\prime} 23 " \mathrm{~N}$ & $79^{\circ} 06^{\prime} 35^{\prime \prime} \mathrm{W}$ & 2 & 5 & 0 & 0 & 0 & 0 & 0 & 0 & 0 & 0 \\
\hline HMNF-QR & HMNF & Q. rubra & 8 & $44^{\circ} 36^{\prime} 37^{\prime \prime N}$ & $83^{\circ} 04^{\prime} 04^{\prime} \mathrm{W}$ & 8 & 0 & 0 & 0 & 0 & 0 & 0 & 0 & 0 & 0 \\
\hline HL-QR & $\mathrm{HL}$ & Q. rubra & 6 & $44^{\circ} 07^{\prime} 00^{\prime \prime} \mathrm{N}$ & $84^{\circ} 45^{\prime} 00^{\prime \prime} \mathrm{W}$ & 6 & 0 & 0 & 0 & 0 & 0 & 0 & 0 & 0 & 0 \\
\hline MTU-QR & MTU & Q. rubra & 8 & $47^{\circ} 06^{\prime} 02^{\prime \prime N}$ & $88^{\circ} 32^{\prime} 51^{\prime \prime W}$ & 7 & 0 & 0 & 0 & 0 & 0 & 0 & 0 & 1 & 0 \\
\hline BR-QR & $\mathrm{BR}$ & Q. rubra & 8 & $47^{\circ} 27^{\prime} 57^{\prime \prime N}$ & $87^{\circ} 54^{\prime} 59^{\prime \prime} \mathrm{W}$ & 6 & 0 & 0 & 0 & 0 & 0 & 0 & 0 & 0 & 1 \\
\hline HC-QR & $\mathrm{HC}$ & Q. rubra & 8 & $35^{\circ} 43^{\prime} 00^{\prime \prime} \mathrm{N}$ & $88^{\circ} 17^{\prime} 00^{\prime \prime} \mathrm{W}$ & 7 & 0 & 0 & 0 & 1 & 0 & 0 & 0 & 0 & 0 \\
\hline $\mathrm{MC}-\mathrm{QR}$ & $\mathrm{MC}$ & Q. rubra & 8 & $34^{\circ} 45^{\prime} 00^{\prime \prime} \mathrm{N}$ & $88^{\circ} 17^{\prime} 00^{\prime \prime} \mathrm{N}$ & 5 & 0 & 1 & 0 & 2 & 0 & 0 & 0 & 0 & 0 \\
\hline RRT-QC & RRT & Q. coccinea & 8 & $37^{\circ} 36^{\prime} 29^{\prime \prime} \mathrm{N}$ & $88^{\circ} 16^{\prime} 17^{\prime \prime W}$ & 7 & 0 & 0 & 1 & 0 & 0 & 0 & 0 & 0 & 0 \\
\hline
\end{tabular}


466 Haplotypes H7 and H9 (see Fig. 1) with restricted geographic distribution that are shared among species pairs are highlighted in grey. FC: Ford Forestry Center, 467 MI; ES: Escanaba, MI; NN: Nicolet National Forest, WI; WR: Wolf Road Prairie, IL; RE: Reforestation Road, WI; HP: Hoosier Prairie, IN; NE: Newaygo, MI; 468 CN: Chequamegon National Forest, WI; OF: Oilfields, MI; HMR: Huron Mountain Reserve, MI; HNF: Hiwatha NF, MI; ONF: Ottawa NF, MI; ANF:

469 Allegheny NF, PA; HMNF: Huron Manistee NF,MI; HL: Halfmoon Lake, MI; MTU: Michigan Technological Trails, MI; BR: Brockway Mountain, MI; HC:

470 Tennessee Henderson County, TN; MC: Madison County, AL; RRT: Rim Rock Trail, IL 
472 Table 2. Haplotype description and frequency

\begin{tabular}{|c|c|c|c|c|c|c|c|c|c|}
\hline \multirow[t]{2}{*}{ Haplotype } & \multicolumn{3}{|c|}{ fragment size (bp) } & \multirow[t]{2}{*}{$\mathrm{f}$} & \multirow[t]{2}{*}{$\mathrm{f}(\%)$} & \multicolumn{4}{|c|}{ species } \\
\hline & ccmp2 & ccmp4 & udt4 & & & Q. rubra & Q. ellipsoidalis & Q. velutir & coccinea \\
\hline 1 & 228 & 116 & 145 & 201 & 70.04 & 74.91 & 68.18 & 57.50 & 87.50 \\
\hline 2 & 228 & 116 & 146 & 13 & 4.53 & 5.71 & 3.41 & 2.50 & \\
\hline 3 & 227 & 116 & 145 & 4 & 1.39 & 1.25 & 2.27 & & \\
\hline 4 & 227 & 116 & 146 & 2 & 0.70 & 0.63 & & & 12.50 \\
\hline 5 & 227 & 115 & 146 & 15 & 5.23 & 6.30 & 4.55 & & \\
\hline 6 & 226 & 116 & 145 & 4 & 1.39 & 0.63 & 2.27 & 2.50 & \\
\hline 7 & 226 & 118 & 146 & 20 & 6.97 & 3.75 & 7.95 & 20.00 & \\
\hline $8^{*}$ & 226 & 118 & 145 & 1 & 0.35 & 0.63 & & & \\
\hline 9 & 226 & 117 & 146 & 11 & 3.83 & & 6.82 & 12.50 & \\
\hline $10^{*}$ & 226 & 115 & 146 & 1 & 0.35 & & 1.14 & & \\
\hline $11^{*}$ & 225 & 116 & 145 & 1 & 0.35 & & & 2.50 & \\
\hline $12 *$ & 229 & 118 & 147 & 1 & 0.35 & 0.63 & & & \\
\hline $13 *$ & 227 & 117 & 145 & 1 & 0.35 & 0.63 & & & \\
\hline $14^{*}$ & 228 & 120 & 145 & 1 & 0.35 & 0.63 & & & \\
\hline $15^{*}$ & 229 & 114 & 143 & 1 & 0.35 & 0.63 & & & \\
\hline
\end{tabular}




$\begin{array}{llllllll}16 & 229 & 116 & 145 & 2 & 0.70 & 1.25 & \\ 17 * & 229 & 116 & 146 & 1 & 0.35 & 0.63 & \\ 18 * & 230 & 116 & 145 & 1 & 0.35 & & 1.14 \\ 19 & 234 & 116 & 145 & 2 & 0.70 & 0.63 & 1.14 \\ 20 * & 224 & 115 & 144 & 1 & 0.35 & & 1.14 \\ 21 * & 226 & 115 & 143 & 1 & 0.35 & 0.63 & \\ 22 & 228 & 116 & 139 & 1 & 0.35 & 0.63 & \\ 23 * & 229 & 117 & 146 & 1 & 0.35 & & \end{array}$

473 f: frequency, *: haplotypes observed in a single population (private haplotypes) 
475 Table 3. Genetic variation within populations

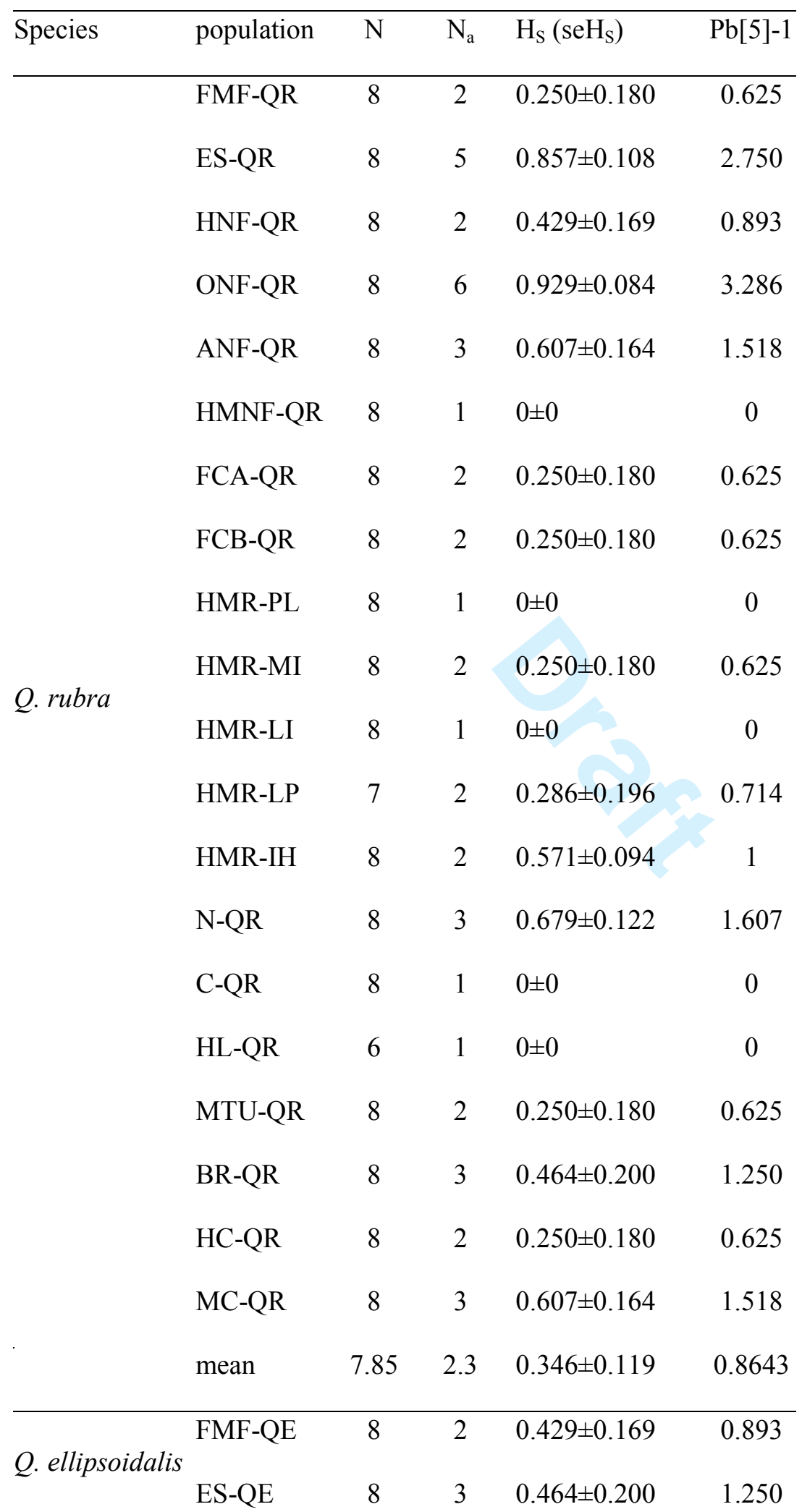




\begin{tabular}{|c|c|c|c|c|c|}
\hline & FCC-QE & 8 & 2 & $0.250 \pm 0.180$ & 0.625 \\
\hline & FCE-QE & 8 & 2 & $0.429 \pm 0.169$ & 0.893 \\
\hline & $\mathrm{N}-\mathrm{QE}$ & 8 & 4 & $0.750 \pm 0.139$ & 2.143 \\
\hline & $\mathrm{C}-\mathrm{QE}$ & 8 & 1 & $0 \pm 0$ & 0 \\
\hline & W-QE & 8 & 3 & $0.679 \pm 0.122$ & 1.607 \\
\hline & $\mathrm{O}-\mathrm{QE}$ & 8 & 3 & $0.607 \pm 0.164$ & 1.518 \\
\hline & R-QE & 5 & 1 & $0 \pm 0$ & 0 \\
\hline & $\mathrm{N}-\mathrm{QE}$ & 8 & 1 & $0 \pm 0$ & 0 \\
\hline & $\mathrm{H}-\mathrm{QE}$ & 8 & 5 & $0.857 \pm 0.108$ & 2.750 \\
\hline & mean & 7.727 & 2.455 & $0.406 \pm 0.114$ & 1.062 \\
\hline & W-QV & 8 & 2 & $0.250 \pm 0.180$ & 0.625 \\
\hline & $\mathrm{O}-\mathrm{QV}$ & 8 & 3 & $0.607 \pm 0.164$ & 1.518 \\
\hline Q. velutina & R-QV & 5 & 1 & $0 \pm 0$ & 0 \\
\hline & N-QV & 8 & 1 & $0 \pm 0$ & 0 \\
\hline & H-QV & 8 & 4 & $0.643 \pm 0.184$ & 1.875 \\
\hline & mean & 7.4 & 2.2 & $0.300 \pm 0.106$ & 0.804 \\
\hline Q. coccinea & RRT-QC & 8 & 3 & $0.607 \pm 0.164$ & 1.518 \\
\hline
\end{tabular}

$476 \mathrm{~N}$ : number of samples, $\mathrm{N}_{\mathrm{a}}$ : number of haplotypes, $\mathrm{H}_{\mathrm{s}}$ : genetic diversity

477 with standard error, $\mathrm{Pb}[5]-1$ : haplotypic richness

478 
479 Table 4. Genetic diversity of each species and differentiation among populations

\begin{tabular}{ccccccc}
\hline species & $\mathrm{H}_{\mathrm{S}}$ & $\mathrm{H}_{\mathrm{T}}$ & $\mathrm{G}_{\mathrm{ST}}$ & $\mathrm{R}_{\mathrm{S}}$ & $\mathrm{R}_{\mathrm{T}}$ & $\mathrm{R}_{\mathrm{ST}}$ \\
\hline Q.rubra & 0.346 & 0.436 & 0.206 & 2.057 & 2.415 & 0.253 \\
Q.ellipsoidalis & 0.406 & 0.536 & 0.243 & 2.062 & 2.518 & 0.301 \\
Q.velutina & 0.300 & 0.709 & 0.577 & 1.804 & 2.873 & 0.571 \\
Overall & 0.355 & 0.491 & 0.277 & 1.935 & 2.393 & 0.329 \\
\hline
\end{tabular}

$480 \quad \mathrm{H}_{\mathrm{S}}$ : genetic diversity within populations, $\mathrm{H}_{\mathrm{T}}$ : total genetic diversity, $\mathrm{R}_{\mathrm{S}}$ : within populations

481 diversity taking mutational differences into account, $\mathrm{R}_{\mathrm{T}}$ : total genetic diversity taking

482 mutational differences into account, $\mathrm{G}_{\mathrm{ST}}$ : genetic differentiation, $\mathrm{R}_{\mathrm{ST}}$ : genetic differentiation

483 taking mutational differences into account.

484

485

Figure Legends

486 Fig. 1. Haplotype distribution shown only for interspecific sympatric stands (see also Table 1).

487 Haplotypes are shared between species in neighboring stands, but differentiated among

488 geographic regions. Region names are included and correspond to names in Table 1.

489 Fig. 2. Haplotype networks excluding haplotypes that occur in only a single sample. Sharing of

490 haplotypes among species $Q$. rubra (Qr), Q. ellipsoidalis $(\mathrm{Qe}), Q$. velutina $(\mathrm{Qv})$ and $Q$. coccinea

491 (Qc) is shown. The size of the circles is proportional to the frequency of haplotypes. 


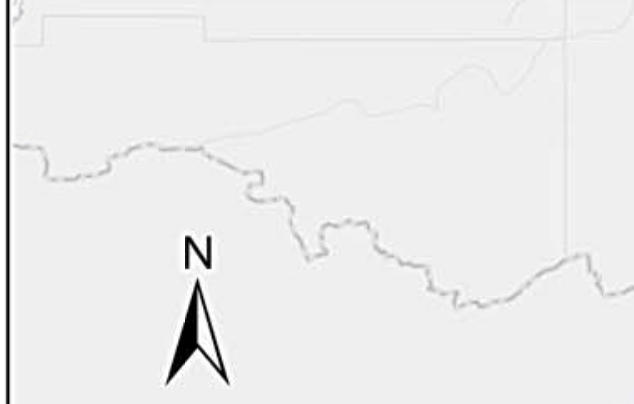

Legend

Export_0utput_27
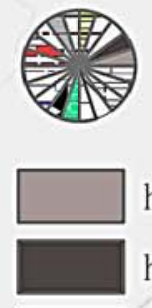

\section{h1}

h2

$\square \mathrm{h} 3$
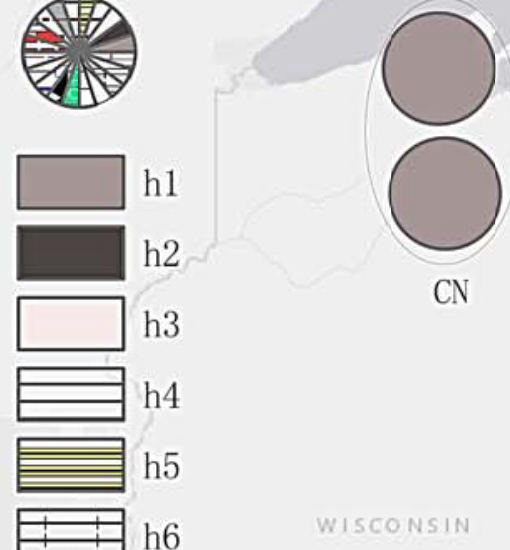

h6

$\mathrm{n}$ …ㄱ…......

E:-:-:- h8

豆䔰 h9

覜垔闻 h10

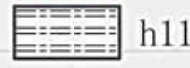

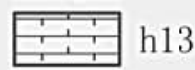

E韭目 $\mathrm{h} 14$

h17

h18

E $\mathrm{h} 19$

MII h20

h21

望 $\mathrm{h} 22$

돋밀 $\mathrm{h} 23$

WISCONSIN

Light Gray Canvas Base

$\begin{array}{lll}0 & 87.5 \quad 175\end{array}$ $350 \mathrm{Km}$

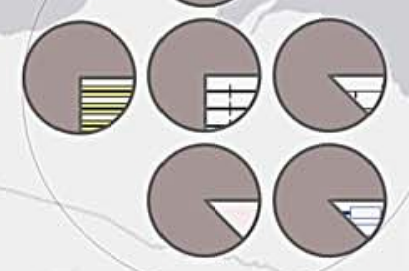

FC

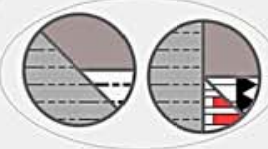

NN

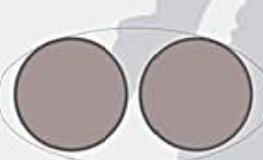

$\mathrm{RE}$

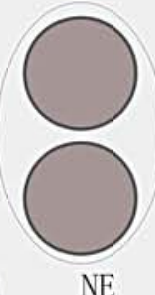

ES

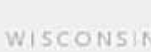

WISCONS4h

14inot

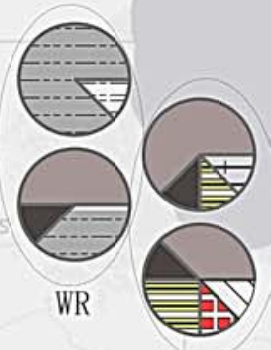

HP

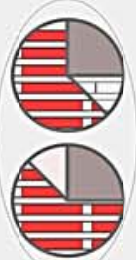

$\mathrm{OF}$ 


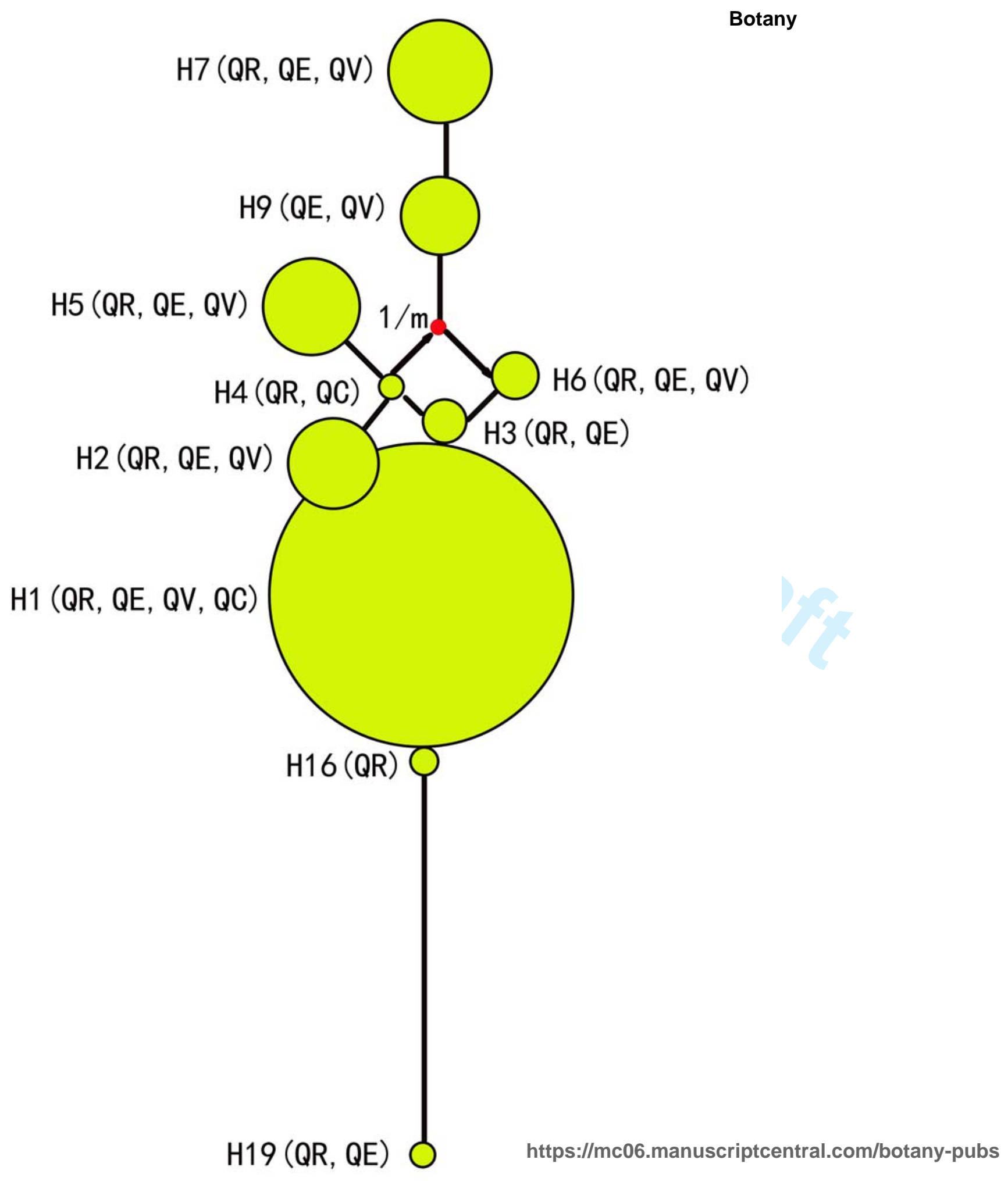

